\title{
Crítica de cinema e política: o filme histórico nos jornais alternativos Opinião e Movimento
}

Margarida Maria Adamatti

Resumo: Durante os anos setenta, o aumento da produção de filmes históricos foi uma das formas encontradas pelo Estado para orientar a produção através do patrocínio da Embrafilme. O presente artigo analisa a abordagem dos críticos dos jornais Opinião e Movimento para avaliar a contribuição da imprensa alternativa sobre os filmes históricos: Independência ou Morte (1972) de Carlos Coimbra, Os inconfidentes (1972) de Joaquim Pedro de Andrade e Sacco e Vanzetti (1971) de Giuliano Montaldo.

Palavras-chave: Crítica de cinema. Filme histórico. Imprensa alternativa. Os Inconfidentes. Sacco e Vanzetti.

O filme histórico sempre foi para os cineastas uma fonte de legitimação importante. Foi ainda sob o impacto de Cabiria de Giovanni Pastrone em 1914, que D. L. Griffith sonhou realizar Intolerância (1916) e também Nascimento de uma nação (1915). No cinema brasileiro não poderia ser diferente. Grandes vultos do passado, pompa e décor apropriado foram os ingredientes principais da concepção de filme histórico na maior parte da nossa filmografia. Os altos custos de produção costumavam afastar os cineastas do filme histórico, mas esta produção sempre existiu de forma ocasional,

\footnotetext{
* Doutoranda no Programa de Pós-Graduação em Meios e Processos Audiovisuais da Escola de Comunicações e Artes da Universidade de São Paulo (ECAUSP). E-mail: mmadamatti@hotmail.com
} 
desde os idos da Bela Época. Se O caçador de diamantes (1933) de Vittorio Capellaro marca uma visão heróica baseada em grandes personagens, a média dos filmes históricos brasileiros não fugiu muito do enaltecimento de vultos históricos, como demonstrou o crítico e professor de cinema Jean-Claude Bernardet (1979-80).

Ainda no final dos anos setenta, Bernardet dedicou-se a analisar as relações entre o filme histórico, o regime militar e a crítica de cinema. O aumento desse tipo de produção teve relação com os mecanismos de pressão ideológica e estética durante o regime militar:

O filme histórico tem sido uma vedete cinematográfica da década. [...] A questão do filme histórico coloca-se realmente na década de 70, embora o gênero já existisse muito antes no cinema brasileiro. A diferença é que, até então, ele vinha sendo esporádica e espontaneamente praticado, enquanto nestes últimos anos ele resulta de determinadas pressões políticas e administrativas. [...] A partir do governo Médici, não se deixa mais à espontaneidade dos cineastas a produção dos filmes históricos. [...] A partir de 1970, a coisa mudou de figura: o Ministério da Educação toma a iniciativa e exorta os cineastas a se voltarem ao filme histórico. Isto é fato novo, o governo manifesta explicitamente o seu desejo (BERNARDET, 1979-80, p. 49).

Essa primeira tentativa, ainda no governo Médici, tentava minimizar a imagem repressora do ponto de vista cultural, mas a estratégia não surtiu efeito por causa dos altos custos de produção, sem retorno garantido para uma produção considerada cara. A segunda tentativa do governo foi financiar o roteiro de filmes históricos, mas também esta ideia não empolgou os cineastas. Dos dois projetos enviados, apenas Anchieta, José do Brasil (1977) de Paulo César Saraceni recebeu aprovação, mas teve uma produção conturbada, e no final não conseguiu obter nem sucesso de público, nem de crítica. Por fim, a Embrafilme decidiu entrar na produção em 1975, criando uma verba especial ao gênero. Em caso de aprovação do argumento pelo Ministro da Educação, o roteiro seria financiado.

Naquela época o filme histórico ideal para o governo era Independência ou Morte (1972) de Carlos Coimbra, produção que não 
recebeu auxílio estatal. O produtor Oswaldo Massaini até tentou obter ajuda oficial, mas sem sucesso. Por isso fez o filme com recursos próprios. Após o sucesso junto ao público, o governo encampou o filme como modelo (SIMÕES, 1981).

As relações de produção do filme histórico entre cineastas e o regime militar não significavam um controle estatal total, uma vez que o governo entrava só com prêmios e financiamentos. O Estado nunca assumiu a produção de filmes, como mostra Jean-Claude Bernardet (1979-80). Graças a isso se conseguiu uma margem de elasticidade no resultado final da produção feita com auxílio estatal, tais como São Bernardo (1972) de Leon Hirszman e Anchieta, José do Brasil (1977) de Paulo César Saraceni. Ambos passaram muito longe da ideia de enaltecimento que o regime militar esperava. Exceção feita ao filme $O$ caçador de esmeraldas (1979) de Osvaldo Oliveira, a tentativa do Estado de utilizar o cinema como forma de enaltecer personagens históricos não saiu a contento, porque não se conseguiu o controle sobre a produção.

Mesmo assim, esse tipo de produção foi a forma mais certeira encontrada pelo Estado para incidir sobre a produção cinematográfica com algum tipo de orientação temática e estética da Embrafilme. Para Jean-Claude Bernardet (1979-80), a intervenção não significou uma tentativa de assumir a produção por parte do Estado, nem de traçar uma perspectiva ideológica, mas esta situação permanecia subentendida. Por um lado, existia uma margem de elasticidade. Por outro, as cartas estavam marcadas pelos sistemas de controle e censura, sem risco para o governo.

A tentativa de incidir sobre a produção cinematográfica não prescindiu do auxílio da crítica de cinema. É sobre ela que centramos nosso olhar para avaliar se a imprensa abriu o debate aos leitores sobre a utilização do filme histórico como fabricação do real. Realizamos uma pesquisa parcial sobre a cobertura jornalística dos principais filmes históricos brasileiros em cartaz nos anos setenta no arquivo da Cinemateca Brasileira. Pudemos constatar uma postura similar e recorrente entre os críticos da grande imprensa. A título de exemplo, trazemos o artigo de Jonald ${ }^{1}$ na revista Filme Cultura. Então diretor da revista A Cena Muda (1921-1955), ele manteve vivo o estilo que caracterizou a publicação, elogiando todos 
Crítica de cinema e política: o filme histórico nos jornais alternativos...

os filmes históricos citados, sem analisar nenhum. O mérito desta produção, segundo ele, é possibilitar a competição com o produto estrangeiro. Num breve artigo, Jonald não adentra no sentido político da produção. Apenas tece elogios a todos os filmes, seja pelo "alto poder de persuasão" e pelos "soberbos destaques" de Descobrimento do Brasil (1937) de Humberto Mauro, que não apresenta "uma falha sequer", seja pela mescla entre realidade e ficção de $A$ guerra dos pelados (1970), de Sylvio Back. Ele utiliza as declarações do produtor Oswaldo Massaini para provar a "total fidelidade, pesquisa histórica e extremo cuidado" na feitura de Independência ou Morte.

Evitando abordar a diferença entre Independência ou Morte e Os Inconfidentes (1972) de Joaquim Pedro de Andrade, Jonald opta por tratar deste último de forma subentendida. Considera o filme uma "adaptação livre de episódios históricos" com um "prisma bem diferente de abordagem", a partir dos textos dos "Autos da Devassa" e dos versos dos poetas da Inconfidência. Fica subentendido que ante ao rigor técnico de Independência ou Morte já mencionado no texto, Os Inconfidentes não passa de uma "interpretação pessoal", como ele afirma. Ou seja, não se trata de um filme histórico em que se possa acreditar como prova de veracidade histórica.

Fato inegável é que Independência ou Morte traz uma visão no mínimo romanceada sobre Dom Pedro I, enquanto o filme de Joaquim Pedro utiliza o episódio da Inconfidência Mineira como forma de abordar o presente, no caso o regime militar. Trata-se da oposição entre um filme de gênero comercial e um filme autoral, aspecto este ocultado no artigo de Jonald.

Nossa pesquisa sobre o tema encontrou o mesmo padrão descrito por Jean-Claude Bernardet. Ainda nos anos setenta, ele foi o primeiro a analisar a postura média dos jornais diários sobre os filmes históricos. Escreve o crítico sobre a relação entre os filmes históricos e o governo:

O governo não formula a visão da história e a estética do filme histórico, mas uma parte do corpo social encarrega-se dessa tarefa: é a crítica. Se examinarmos grande parte das críticas jornalísticas referentes a filmes históricos, verificaremos que os críticos não costumam formular explicitamente as suas 
posições ideológicas e estéticas, mas estas podem ser deduzidas com facilidade dos textos, elas vêm à tona. Chamarei de 'naturalismo' o princípio básico que perpassa pela maior parte das críticas e sustenta o juízo sobre os filmes. [...]. Por que essa busca do naturalismo? [...] O naturalismo - no sentido em que estou usando a palavra - dá uma impressão de veracidade, de autenticidade, e elimina, ou deve eliminar, as marcas do trabalho, as marcas da fala. Não se deve perceber que alguém fez o filme, que o filme é um trabalho sobre a história, que é uma interpretação, que poderia haver outras. Se pode haver outras interpretações, a que está na tela não é necessariamente a verdadeira, ou as outras podem ser igualmente verdadeiras. É necessário eliminar essa dúvida para que não se questione a verdade da tela. E essa verdade é indispensável à ideologia dominante, pois, para dominar, ela não pode apresentar-se nem como ideologia, nem como uma visão da história entre outras. A luta estética pelo naturalismo é uma luta ideológica; a estética não pode abrir brecha na interpretação dominante, sob pena de ameaçála como verdade. E é somente enquanto ela se apresenta como verdade incosteste e sem falha que ela pode ser transmitida e aceita como a verdade, como a História. A História é assim. O trunfo não é pequeno. Para a dominação ideológica é indispensável dominar a história, já que a história é sempre uma interpretação do presente. Impor uma visão da história é impor uma maneira da sociedade se pensar no presente. Por isso é um campo de intensa luta ideológica (BERNARDET, 1979-80, p. 55).

Qual seria então, a função da crítica de cinema frente aos filmes históricos? Analisando os textos de época, Bernardet conclui que o crítico auxiliou em grande parte o processo de construção de uma dada visão da História. Ele observou não só a preferência pelo naturalismo na crítica, mas por uma preocupação crescente destes críticos com a impressão de realidade e familiaridade das fitas, com o décor apropriado e com a interpretação naturalista dos atores: 
Crítica de cinema e política: o filme histórico nos jornais alternativos...

O crítico pretende poder acreditar nas imagens, que elas the dêem a impressão de que estaria vendo verdadeiramente um verdadeiro momento da história. Ele quer acreditar. Ele quer que o filme lhe possibilite uma relação de familiaridade com a história, ainda mais em filmes que querem criar esta familiaridade. O que perturba essa relação - a história como se eu a estivesse vendo - é defeito (BERNARDET, 1979-80, p. 56).

Segundo ele, o crítico queria acreditar no filme histórico como verdade, eliminando a consciência de que todo filme é um trabalho sobre a história. Sem precisar explicitar aos leitores sua posição ideológica ou estética, o crítico se encarregaria, assim, de formular uma visão da história e estética do filme histórico, através de suas preferências, sem que o Estado tivesse que se encarregar desta função.

Se como vimos, a postura média da imprensa sobre o filme histórico, tanto na pesquisa de Jean-Claude Bernardet, como no nosso levantamento, indicou uma preocupação crescente com a veracidade histórica, resta avaliar se algum órgão da imprensa, destinado ao grande público leitor, enveredou por um caminho diferente. E nesse caminho encontramos os críticos que se reuniam em torno de dois jornais alternativos de base política: Opinião (1972-1977) e Movimento (1975-1981). Ambos os jornais contribuíram com a disseminação de um pensamento historiográfico oposto ao praticado pela grande imprensa, afinal foi a relação indissociável entre política e cinema que mudou a visão tradicional sobre a função da crítica de cinema.

A partir dos anos sessenta se amplia um processo de modernização da crítica de cinema, que saia do âmbito estritamente estético, para extrapolar suas fronteiras em direção à política e aos autores de outros campos de estudo. (BAECQUE, 2010) A trajetória da revista Cahiers du Cinéma é indicativa nesse sentido, quando se coloca em segundo plano o estudo da mise en scène, elegendo como tema principal as relações entre política e ideologia na análise dos filmes. (WILSON, 2000) Dessa forma, tanto a produção intelectual quanto a crítica de cinema são vistas como ferramentas de mudanças sociais. O tipo de crítica desse período é chamado por Bywater; Sobchack (1989) de crítica teórica por conjugar as influências da ciência da linguagem, do estruturalismo, do marxismo, do neofreudianismo 
e dos estudos feministas. Um dos nortes desse período, segundo Xavier (2005), era identificar no discurso fílmico a produção de sentido, relacionando o modo de produção com o contexto social, político e ideológico para aumentar a consciência dos efeitos da linguagem.

$O$ que se pretendia na crítica mundial também era pensado na crítica de cinema dos jornais alternativos: revelar o discurso por detrás do filme aos leitores para aumentar a consciência dos efeitos da linguagem. No caso especificamente brasileiro, o contexto do regime militar mudava bastante o olhar dos críticos.

Após o decreto do Ato Institucional Número 5 (AI-5), as mínimas condições de existência de um jornalismo crítico se dissiparam. Para preencher o espaço perdido com o fechamento dos espaços de resistência na grande imprensa surgiram os jornais alternativos, como opções de opinião e informação diferentes das difundidas nos grandes periódicos. O termo foi cunhado ainda nos anos setenta por Alberto Dines, como a única parte da imprensa que fazia perguntas e questionava. Como instrumento de resistência e oposição intransigente ao regime militar, a imprensa alternativa denunciava e questionava o milagre econômico, o acordo atômico brasileiro, a tortura e a violação de direitos humanos (KUCINSKI, 1991; MARCONI, 1980).

Fenômeno mais característico dos anos setenta, o papel da imprensa alternativa como jornalismo engajado é indiscutível. Durante o período de 1964-1980, nasceram e morreram cerca de 150 jornais alternativos que possuíam como traço comum a oposição intransigente ao regime militar. Sofrendo com intensa censura e repressão, jornais como Opinião, Movimento, Pasquim, Bondinho, Ex, Em Tempo, Versus, Repórter, Coojornal e Crítica formaram espaços de reorganização política e ideológica da esquerda.

A história dos jornais alternativos de base política, como Opinião e Movimento, está diretamente atrelada à história da linhagem de veículos dirigidos por Raimundo Rodrigues Pereira. Em 1972, o empresário Fernando Gasparian criou o jornal de oposição Opinião. Sob o comando do editor Raimundo Pereira, o semanário tornou-se ponto de encontro da oposição, caracterizado pelo debate e diversidade de opiniões. O veículo teve de se submeter à censura prévia em Brasília, enfrentando também um atentado à bomba e a prisão de seus dirigentes, além de ameaças de morte. 
Crítica de cinema e política: o filme histórico nos jornais alternativos...

As divergências entre o proprietário do jornal e o editor cresceram paulatinamente, ocasionando a dissolução do acordo em 1974. Em 1975, quase dois anos antes do fechamento de Opinião, nascia Movimento, um jornal de propriedade coletiva de jornalistas, sob o comando do sócio fundador Raimundo Pereira. Movimento foi o único veículo da imprensa alternativa a receber censura prévia desde o número zero, numa época de abrandamento da censura aos jornais. Com um episódio de invasão e quebra da redação, o semanário permaneceu por seis anos no mercado, três deles marcados pela censura prévia em Brasília.

O projeto editorial de Opinião e Movimento fornecia às seções culturais um espaço semelhante às demais editorias, relacionando a produção cultural à política. Foi ao redor da imprensa alternativa que se aglutinaram críticos de cinema, como Jean Claude Bernardet, Sérgio Augusto, Paulo Emilio Salles Gomes, Maria Rita Kehl, Gustavo Dahl, entre outros. E foi muitas vezes nestes espaços que tais críticos compuseram críticas sobre o cinema brasileiro que se tornaram referencias.

Como se trata de uma produção em pauta pela tentativa de orientar a produção cinematográfica, os filmes históricos tornaram-se um tema recorrente nos dois jornais alternativos estudados, especialmente nos artigos de Jean-Claude Bernardet tanto em Movimento quanto em Opinião. Os dois filmes históricos brasileiros mais comentados são Os inconfidentes (1972) de Joaquim Pedro de Andrade e Independência ou Morte (1972) de Carlos Coimbra. É interessante frisar que mesmo após anos do lançamento, os dois filmes são citados com frequência nos artigos. Em Opinião, Jean-Claude Bernardet faz questão de acompanhar e comparar a produção de Joaquim Pedro de Andrade em dois momentos: Os inconfidentes e Guerra Conjugal. Um filme histórico e uma comédia erótica. Sob esse invólucro de filme de gênero, o crítico revela aos leitores que o cineasta não se vendeu ao inimigo, no caso o Estado e o mercado ${ }^{2}$ :

Nestes dois filmes, [...] é como se Joaquim Pedro aceitasse um desafio: o negócio é a pornochanchada, pois 'vamos lá'. Joaquim Pedro, que tantas vezes, em entrevistas, se pronunciou contra os aspectos reacionários da comédia erótica, 
como que aceita as armas do inimigo, mas é para usá-las num sentido oposto. Penetrar no terreno do inimigo e fazer o contrário do que as regras do jogo prevêem. Esta parece ser uma das significações mais importantes do trabalho que Joaquim Pedro vem desenvolvendo.

Contra o jogo - Neste sentido, Guerra Conjugal, apesar das aparências, está diretamente relacionado com Os inconfidentes. Em 1972, ano dos festejos do sesquicentenário, ano do filme de Oswaldo Massaini, Independência ou Morte, num momento em que o ministro da Educação reclamava que se fizessem filmes históricos, Joaquim Pedro realiza um filme histórico sobre a Inconfidência Mineira, aparentemente entrando na onda e atendendo às expectativas expressas pelo governo. Em realidade, ele aceita as armas propostas pelo parceiro, mas é para voltá-las contra os objetivos almejados por esse parceiro.

Joaquim Pedro finge aceitar a regra do jogo, penetra e mina por dentro. Os inconfidentes não apresentou uma concepção gloriosa e heróica, e no fundo marcada e ingênua, da história do Brasil. Os Inconfidentes representa o mais alto grau de contradições a que chegaram os intelectuais-cineastas na época, e o grande valor do filme é justamente o de ter feito aflorar claramente estas contradições (Opinião, p. 20, 11/04/1975).

Aqui, Bernardet quer esclarecer que Joaquim Pedro utiliza o formato da pornochanchada em Guerra Conjugale do filme histórico em Inconfidentes, que são as armas dadas pelo inimigo, leia-se governo e imperativo de público, para inverter seus propósitos. Não para criar um espetáculo, mas para gerar reflexão crítica no espectador. Esse é o tipo de filme histórico que Jean-Claude Bernardet elogia, trata-se, portanto, de uma defesa de um cinema que faça o espectador pensar. Em síntese, uma defesa do cinema moderno brasileiro. Já no jornal Movimento, Jean-Claude Bernardet retoma a oposição entre Os inconfidentes e Independência ou Morte para avaliar a ideologia por detrás da produção ${ }^{3}$. Primeiro, ele explica que os filmes históricos são mais comuns na época do "nacionalismo estilo amor 
à pátria", lembrando que tais filmes têm um "compromisso" com a época histórica de que tratam, mas também com o período em que são feitos. Os interesses são, portanto, sempre atuais:

Todo filme histórico (todo filme que aborda o passado com um certo recuo de tempo) estabelece um compromisso não só com o período que aborda, mas também e essencialmente, com a época em que é produzido. Os motivos que levam à realização de um filme histórico - análise política de um fato, escapismo, modas passadistas, interesses comerciais, etc - são sempre razões atuais. A tendência é forte, portanto, de apresentar interpretações históricas que sejam projeções sobre o passado de posições políticas atuais. $\mathrm{O}$ filme histórico nos leva a questionar quais são essas posições políticas atuais, qual a ideologia e a metodologia que decorrem delas, qual a manipulação que resulta desse processo.

Tomando dois exemplos, tanto Os Inconfidentes (Joaquim Pedro de Andrade, 1972) como Independência ou Morte (Carlos Coimbra, 1972) servirão de material para essa discussão. Dois filmes históricos que apresentam imagens 'reconstituídas' do passado e que remetem um pouco ao passado, muito do presente e por isto dois filmes políticos. Dois filmes que interpretam a história à luz de preocupações atuais. Mas essas preocupações são opostas. Para nos fazer aceitar hoje uma certa imagem do líder, do chefe de Estado, Independência ou Morte, filme político militante, apresenta um Dom Pedro I que se relaciona harmoniosamente com o povo, numa sociedade sem conflitos sociais. Enquanto que Os Inconfidentes procura fazer da Inconfidência uma leitura que explicite justamente conflitos sociais que deverão nos esclarecer sobre aspectos da sociedade atual.

São dois filmes que trabalham a dois níveis (o nível da atualidade e o nível histórico), partem do presente, passam pela história e chegam ao presente. Para que este mecanismo funcione, é necessário que sejam encontradas analogias entre o presente e o período histórico focalizado. Tornam-se 
mais importantes estas analogias do que a estrutura específica tanto do presente como do passado. De fato, uma análise aprofundada da época dificultaria, ou impediria o seu relacionamento com o presente. Esse processo leva em geral a uma visão excessivamente simplificada tanto do presente como do passado. O uso metafórico da história leva a tratar a política presente e passada num nível de abstração tal que a especificidade dos conflitos pode até desaparecer completamente. [...] Resta a saber também a quem interessa um uso da história que valorize o jogo das analogias e tende a fazer desaparecer a especificidade dos conflitos (Movimento, p. 21, 04/04/1975).

A partir desta comparação, o autor mostra que os dois filmes têm preocupações políticas opostas. Independência ou Morte induz o espectador a pensar que vê a história pelo "buraco da fechadura", escondendo os conflitos sociais de Dom Pedro I com o povo. Bernardet desconstrói o filme ao lembrar que o filme de Coimbra mostra um Dom Pedro I que se relaciona de forma harmoniosa com seu povo. Ao contrário, Os Inconfidentes faz do episódio histórico uma leitura para explicar os conflitos sociais da atualidade. Ainda sobre a diferença dos dois filmes históricos, Bernardet explica:

[...] Um outro ponto que opõe Os inconfidentes a Independência ou Morte é a representação da história. O filme de C. Coimbra induz o espectador ingênuo a pensar que está olhando pelo buraco da fechadura da história, como se estivesse vendo autênticas cenas do passado. Tenta-se confundir o espetáculo com o real. Já Os Inconfidentes denuncia o espetáculo; para Joaquim Pedro, a representação da história é possível, desde que se afirme não como história mas como representação. A encenação do filme, a interpretação dos atores explicitam que o filme é um artifício, não um pedaço de história que teria chegado até nós. $\mathrm{Na}$ sequência final, em que são confrontadas a história e a comemoração da história (festejos de 21 de abril), ficam claros tanto o artifício do espetáculo como a relação história/presente (Movimento, 04/04/1975). 
Crítica de cinema e política: o filme histórico nos jornais alternativos...

Bernardet esclarece aos leitores que ambos os filmes falam muito sobre o presente, por isso são filmes políticos. Mas que, ao tratar da política num nível de abstração, as especificidades do conflito desaparecem em Independência ou Morte. Os dois filmes têm preocupações opostas. Joaquim Pedro quer mostrar que a representação da história é possível desde que ela se afirme como representação, não como história. Ao afirmar apenas que se trata de um filme que fala sobre o presente como qualquer filme histórico, Jean Claude Bernardet deixa subentendido nas entrelinhas uma das formas encontradas por Joaquim Pedro para abordar o regime militar.

Os censores analisaram Os inconfidentes sem encontrar nada de "subversivo", mas ficaram desconfiados, afinal Joaquim Pedro fazia parte da lista de suspeitos. Concordaram que o filme enaltecia os vultos históricos, especialmente Tiradentes, mas ficaram preocupados com uma frase: "Precisamos tomar cuidado para o poder não cair nas mãos dos militares". Por esse motivo, chamaram um professor de história que garantiu que o filme era a melhor produção sobre a Inconfidência Mineira (SIMÕES, 1999). O que esta crítica deixou de expor com todas as letras foram as formas utilizadas para se referir à ditadura militar nas cenas em que os inconfidentes encaram a câmera, como se dialogassem com o espectador.

Edições depois, Bernardet relaciona de forma indireta o conteúdo do filme histórico com a política cinematográfica, quando aborda a preferência do Estado em patrocinar e financiar filmes históricos ${ }^{4}$, como forma de conseguir gerar uma hegemonia da cultura. Para o Estado, o filme histórico é a produção perfeita para se colocar no lugar da pornochanchada porque não reflete uma imagem negativa do Brasil.

Durante a década de setenta, as discussões sobre cinema, política e ideologia norteavam o pensamento de muitos críticos ao redor do mundo. No caso específico brasileiro, sabemos que por volta de 1978-79, Jean-Claude Bernardet formou um grupo interdisciplinar para discutir a relação entre cinema e história a partir da obra de Marc Ferro (CAPELATO, 2007).

As análises de Marc Ferro sobre as relações entre história e cinema permanecem inconclusas em alguns pontos por causa da brevidade com que o autor tratou o tema, mas cabe a ele o mérito de trazer para a Nova História o cinema como objeto de estudo. 
Eduardo Morettin avalia que a principal deficiência do trabalho de Ferro foi a de perder o caráter polissêmico da imagem, além da crença na existência de documento autêntico que só é perceptível ao historiador (CAPELATO, 2007).

Destacamos aqui a possibilidade de estabelecer alguns pontos de contato entre a obra de Ferro e os comentários da imprensa alternativa sobre os filmes históricos. Para Ferro, o cinema é um documento privilegiado da sociedade e de seu tempo porque traz lapsos, ou seja, informações que confrontam as intenções de quem filma. As películas de reconstituição histórica, são para Ferro, documentos importantes porque dizem respeito ao presente, o que é perceptível pela escolha dos temas. Portanto, o passado reconstituído é na verdade um passado mediatizado pelo presente, conceito este também constante na imprensa alternativa.

Também para Pierre Sorlin, o filme histórico é aquele que olhando para o passado, procura interferir nas lutas políticas do presente. Ou seja, ele encena o passado com os olhos voltados para os dias atuais. Por este motivo, todo filme histórico é um filme de ficção, porque "ficção e história se sobrepõem constantemente uma sobre a outra. E é impossível estudar a segunda ignorando a primeira" (SORLIN apud RAMOS, 2002, p. 34).

Quando a imprensa alternativa denunciava a tentativa dos filmes históricos de criar uma concepção de história como a da verdade revelada, ao invés de mostrá-la como representação, ela também está debatendo a monumentalização fílmica da História5. A base para se discutir o conceito de monumentalização fílmica deriva da análise de Jacques Le Goff (1998), que divide a memória coletiva no estudo historiográfico em dois tipos de materiais: os documentos e os monumentos. Os monumentos são criados para transmitir uma determinada herança do passado. São, portanto, marca de poder com a intenção de edificação. Já os documentos eram vistos pelos historiadores positivistas como uma escolha do historiador. Le Goff mostra que todo documento é um monumento porque também foi fabricado para perpetrar uma determinada visão de si ao futuro. Ou seja, também envolve as relações de poder com a sociedade. Assim, cada documento é ao mesmo tempo verdadeiro e falso porque se trata de um instrumento de poder. 
Crítica de cinema e política: o filme histórico nos jornais alternativos...

Este processo de desconstrução do monumento fílmico por parte dos historiadores reflete-se também na imprensa alternativa, quando Jean-Claude Bernardet invertia as bases do senso comum sobre a qualidade expressa através da veracidade histórica e a impressão de realidade. A imprensa alternativa procurou mostrar que o filme histórico é sempre uma representação, carregado de imaginários que muitas vezes transpassam a autoria do diretor. Ao mesmo tempo, ela também desconstruía os monumentos fílmicos, revelando as camadas historiográficas. Afinal, a monumentalização de personagens encontrou um grande potencial de realização na historiografia do cinema, porque todo filme pode ser tomado como documento histórico de uma época.

Diferente de Jean-Claude Bernardet, os artigos de Sérgio Augusto sobre os filmes históricos não enfocam o processo de ocultação da realidade, nem explicitam que o cinema é ao mesmo tempo discurso e representação. $O$ ponto inicial para os comentários do cronista é a análise da produção do período, mas foi por causa de um filme histórico ou de um "falso filme militante", como definiu Augusto, que se acendeu uma polêmica entre ele e os leitores de Opinião.

A controvérsia surgiu por causa do filme Sacco e Vanzetti (1971) de Giuliano Montaldo que aborda o processo judicial verídico de dois imigrantes italianos, o sapateiro Nicola Sacco e do peixeiro Bartolomeu Vanzetti, condenados à cadeira elétrica nos Estados Unidos pela acusação de realizar um atentado anarquista nos anos vinte. O filme era considerado um filme político de esquerda em todo o mundo. O artigo de Sérgio Augusto é publicado durante o lançamento do filme no Brasil, mas naquela mesma semana o general Antonio Bandeira baixou uma portaria no dia 20 de junho de 1973 proibindo a exibição de dez filmes, que já tinham sido liberados pela Divisão de Censura. O filme de Montaldo integrava a lista, encabeçada por filmes de grande prestígio cultural e artístico. Sacco e Vanzetti permaneceu interditado por seis anos, até 1979, embora dois censores tenham votado pela liberação do filme porque a revolta contra o julgamento injusto, segundo eles, não fazia paralelo algum com o Brasil (SIMÕES, 1999).

Alguns comentários externos ao artigo de Augusto são importantes para entender o desentendimento entre ele e seus leitores. Diferentemente do que pensavam os missivistas das seções de cartas 
do jornal Opinião, como veremos mais à frente, o filme de Montaldo não era para os padrões da crítica de esquerda do período um filme de verdadeira contestação. Ele adentraria mais no que alguns críticos chamavam de filmes "contestatários", ou seja, filmes que fingem atacar uma ideologia para defendê-la, ocultando a realidade. Eles serviriam, portanto, aos interesses da classe dominante e não gerariam reflexão crítica no leitor (AMENGUAL, 1975).

O filme de Montaldo não faz parte do cinema moderno. Ao contrário, as informações já estão todas prontas para o entendimento completo dos dados. Ao assistir ao filme, o espectador sai da sala de cinema sem dúvidas. Sem levar em conta a discussão do período sobre os filmes contestatários, podemos dizer que também não se trata de uma produção aberta à reflexão do espectador ou às indagações sobre a culpa dos acusados porque o diretor parte da certeza da inocência dos personagens. Em síntese, Sacco e Vanzetti é um filme melodramático que humaniza e vitimiza os personagens. Pode-se considerar, por outro lado, que esse tipo de produção possa ter maior efeito junto a um determinado público, do que um filme de Godard, tópico este a que voltaremos mais à frente. Só que os críticos de Opinião nunca admitiram isso, porque havia uma preferência por um cinema autoral, moderno e engajado. Além disso, estes críticos condenavam produções melodramáticas, consideradas "esquemáticas", que estabelecessem somente um tipo de leitura.

Depois dessas explicações preliminares sobre o filme e sobre a crítica, podemos voltar ao artigo de Sérgio Augusto ${ }^{6}$, que começa por uma contextualização histórica sobre o caso. Ele explica ao leitor as dúvidas que ainda pairavam sobre a inocência ou responsabilidade dos acusados para mostrar como o diretor Montaldo partiu de uma certeza de inocência, quando deveria mostrar as dúvidas sobre o caso sem apelar ao sentimentalismo. A crítica negativa ao filme inclui a utilização do tom do documentário como prova documental, a certeza da inocência dos anarquistas e a utilização do maniqueísmo:

[...] Guilano Montaldo começa a contar a sua versão do processo, com o falso ar de documentarista deformado pelas paixões do sectarismo. Sacco e Vanzetti não é como prometeu o cineasta, um filme didático sobre um caso complicado e sim uma defesa simplista e parcialíssima de dois anarquistas. 
Montaldo parte da certeza de que, além de inocentes, Sacco e Vanzetti foram vítimas de um sistema diabólico disposto a apelar, se necessário, à corrupção de seus mais alto valores (no caso, a Justiça) para punir os seus inimigos. Um argumento de partisan (o que diminui bastante e o interesse e o valor de sua obra) e insustentável quando se sabe que a inocência dos dois jamais foi provada de forma irrefutável (Opinião, p. 21, 19 a 26 mar. 1973).

Na continuação do artigo, Augusto mostra que Montaldo cortou as cenas com depoimentos de testemunhas oculares que gerariam incerteza para manter intacta a impressão de veracidade histórica. Ao invés de tentar produzir uma obra aberta com ambiguidades, o diretor preferiu criar heróis planificados num mundo corrupto:

[...] Entre as 'certezas' de Montaldo está o crime de Braintree: ele o reconstitui com o requinte de uma testemunha ocular, ao passo que coloca fora de foco a visão do mesmo crime oferecida pelas personagens identificadas como as verdadeiras testemunhas oculares. A honestidade exigia do diretor, no mínimo, uma posição pirandelliana. Com uma retórica semelhante à dos suspenses-políticos de Costa Gravas - gênio da moda e que não passa de um subproduto de velhos policiais de Hollywood, liberalóides ou não - Sacco e Vanzetti é tão comprometido com a verdade histórica, ou com os autos dos processos, quanto as biografias romanceadas de heróis da pátria. As aparências não enganam: as cenas 'fingindo documentário' do começo e do fim não chegam para fazer o espectador mais atento se esquecer de que o resto foi rodado a cores exatamente por razões de glamour. E descamba-se para o mais deslavado melodrama de tribunal, em que tudo é permitido, desde excessos de 'coincidências'[...] ao maniqueísmo gagá: quem está ao lado dos réus é bom; quem está contra é desumano ou imbecil (Opinião, 19 a 26 mar. 1973).

Ao comparar Montaldo a Costa Gravas por enxergar nos dois o gênero policial norte-americano, Augusto reenfatiza os excessos de melodrama, de coincidência e de maniqueísmo nas cenas 
do tribunal, onde o tom de documentário só tem por função mostrar o "glamour do colorido" das demais cenas. Trata-se de uma condenação a alguns dos princípios do melodrama clássico, por não gerar reflexão crítica.

Não se trata de afirmar que Sérgio Augusto busque a veracidade histórica como os críticos faziam com esta produção. Ao contrário, ele condena indiretamente a utilização do filtro da impressão de realidade e da ideia de veracidade histórica que Montaldo tenta provar e o faz, aqui parafraseamos Jean-Claude Bernardet, com "as armas do inimigo", ou seja, com a própria ideia de veracidade histórica. Como há ainda muitas dúvidas e poucas certezas sobre a inocência dos dois anarquistas, o filme deveria expor tais ambiguidades, não gerar certezas falsas. A condenação aqui é ao uso do melodrama e do maniqueísmo. Augusto enfatiza as provas documentais porque toda a discussão sobre Sacco e Vanzetti se baseia nestes termos. O arcabouço foi necessário à proposta do filme, porque o debate sobre a veracidade histórica emerge como tema central para a própria construção fílmica.

Talvez tenha faltado explicar aos leitores neste texto porque se questionava a utilização do melodrama e do cinema clássico hollywoodiano para permitir o maior entendimento dos parâmetros estéticos de Augusto. Comentar também que além da divisão maniqueísta entre bons e maus de Sacco e Vanzetti, o filme ainda apela à comoção por meio das imagens das esposas chorando e da trilha sonora em tom de ode sobreposta às imagens apresentadas como documentais. Contudo, o filme não provoca um sentimento total de passividade porque não existe uma justiça poética no final, como na filmografia de Costa Gravas.

O sentimento possível de indignação ou de espanto do público parte de um tipo de identificação primária do espectador com os personagens, a partir das tensões de um filme de suspense clássico. Para entender o mecanismo de identificação entre personagem, platéia e espectador, José Carlos Avellar disseca a dualidade entre a estrutura dramática simples entre heróis e bandidos do filme e a complexidade da estrutura de identificação. O espectador é colocado num esquema de identificação com os personagens porque ambos são forçados a permanecer sentados, imóveis e calados no 
meio da cena, sem poder participar da ação. Também Sacco e Vanzetti são reduzidos a espectadores de seu julgamento, compartilhando o sofrimento com o público. Ao inverter os papéis entre personagem e espectador, a projeção se dá dos personagens da tela com a platéia para causar a identificação do público com estes últimos, e não diretamente com os personagens como é comum (PRUDENZI, 2006).

Avellar confere ao filme um mecanismo que permite a participação do público. Segundo ele, o espectador é o centro do filme e protagonista da narrativa durante todo o tempo do júri. Esse processo permite ao público analisar sua própria condição. $\mathrm{O}$ mecanismo de funcionamento parte da composição da imagem sobre o ponto de onde o espectador vê a cena. Dessa forma, a construção do filme apresenta-se como dependente do olhar do espectador.

A crítica negativa de Sérgio Augusto a um filme que era considerado militante acendeu uma polêmica na Coluna dos Leitores de Opinião. Em entrevista a Fernanda Camargo (2009), Sérgio Augusto contou que a controvérsia gerou um clima hostil até mesmo na redação do jornal, quando um dos tradutores chegou a investir contra ele e declarar que o mandaria embora se pudesse por "desvio ideológico". Augusto considerou este episódio um dos mais importantes de sua passagem pelo jornal. A questão envolveu dois motivos. Primeiro porque Augusto declarou-se "excessivamente condescendente" com o lançamento do filme Ensina-me a viver (1971) de Hal Ashby, um filme mais "afetado" do que "significativo e politizado". Depois, foi "implacável com as apelações sensacionalistas e as liberdades históricas tomadas por Montaldo", porque se tratava de um "falso filme de esquerda". De acordo com ele, foram os leitores "ideologicamente estreitos" que se revoltaram.

A base de contestação dos leitores baseou-se na comparação entre o filme e o livro original ${ }^{7}$, ou seja, na ideia de que o cinema deve ser fiel à literatura e à história. O leitor José Luiz A. da Silva chama Sérgio Augusto de "minicrítico a-histórico e apolítico", e o condena por seu envelhecimento político. Julga conhecer o "espírito" do jornal que, segundo ele, não condiz com o tratamento acima das "implicações sociais" dado por Sérgio Augusto. A visão do missivista é a de que existe uma obrigação em Opinião de relacionar cinema e política, minimizando as questões de ordem estética. Aqui 
o cinema é apreendido em dependência do fator social, não como arte autônoma. Segundo ele, houve uma "violência" porque "todo o sentido do filme foi deturpado. Sacco e Vanzetti merecia uma crítica mais adequada, profunda". A ideia de deturpar o sentido do filme parte do pressuposto de que a crítica deve revelar uma verdade presente no filme, deve iluminar o leitor. Exigir uma crítica mais adequada ou profunda é uma tentativa do leitor de influenciar o gosto do crítico, como o que se faz nas críticas vinculadas à propaganda dos filmes. O que muda aqui é o tipo de propaganda, no caso, a política de esquerda.

A argumentação do leitor parte de duas linhas de raciocínio diferentes. Dependendo do argumento, o leitor questiona Sérgio Augusto por declarar ter certeza dos fatos quando não há comprovação científica e histórica. Depois, tenta provar "outras" certezas quando as afirmações lhe convêm. Semelhante é a argumentação do leitor João Carlos Corriandre. Acusando Augusto de não ter lido o livro inteiro, recomenda sua leitura para ter "instrumental básico para analisar o filme" e conseguir "entrar com o pé direito na História e nas observações corretas". Ou seja, para o leitor, o cinema é apenas uma ferramenta para analisar a história, longe da ideia de que o cinema independe da fidelidade à literatura.

Apelando mais uma vez ao critério da veracidade histórica, ele compara Sacco e Vanzetti ao filme Os Inconfidentes, colocando em pauta o uso da poesia de Cecília Meirelles e sua adequação ao filme histórico. Modificando "detalhes da história real", o filme de Joaquim Pedro "teve maior relevância". Só que o leitor expõe sua argumentação ao lado da veracidade histórica, e portanto, contrário indiretamente ao filme Os inconfidentes. Para provar a tese, recorre às declarações do próprio diretor Montaldo:

Meu filme está engajado numa realidade mais universal, na medida em que foi concebido como um discurso rigorosamente motivado no terreno histórico, onde nada se inventou e tudo se baseia numa documentação autêntica. Certamente o filme trata de sintetizar os dados e reelaborá-los à luz de um juízo ético-político que não se conforma em descrever os fatos de um modo impressionista (Opinião, p. 2, 09 a 16 abr. 1973). 
A comparação é muito explícita. O filme de Montaldo é melhor porque parte de uma certeza histórica dada, enquanto Joaquim Pedro quer falar sobre o presente, usando como recurso o passado. A frase é muito parecida com a do produtor Oswaldo Maissini, já citada por Jonald, e não oferece espaço para o espectador questionar e refletir sobre o passado representado. Vale pontuar também que num primeiro momento o filme é apresentado como "documentação autêntica" pelo diretor, mas na frase seguinte fala-se em reelaboração com juízo ético-político. Ou seja, a ficção se permite uma reinterpretação ou reconstrução, desde que seja política e ética. Ao perceber a brecha na argumentação, o leitor explica que Montaldo foi "[...] mais puro, não inventando nada que não tivesse base em documentação autêntica".

Sérgio Augusto rebate as críticas dos leitores duas edições após o ocorrido. Utiliza a mesma linha de raciocínio: a veracidade histórica e a falta de ambiguidades do filme ${ }^{8}$. Cita as páginas de onde tirou suas frases e insiste em sua linha de argumentação. Pede desculpas por sua crítica "paternalista" a Ensina-me a viver (1971) de Hal Ashby porque considera o filme "ironicamente" uma arte para "a classe média”, como também Sacco e Vanzetti é um filme político para a classe média. Declara que a polêmica "provinciana e estéril" sobre a crítica dele não o espantou porque só participaram dela pessoas devidamente instruídas sobre o caso, discutindo suas implicações sociopolíticas. Por fim, completa sobre a questão da utilidade da arte:

Meus críticos acreditam, com um fanatismo religioso, que toda arte é ou deve ser utilitária, ponto de vista discutível na medida em que faltam dados históricos para provar a eficácia desse utilitarismo. Eu, pessoalmente, gostaria que um filme tivesse a força de um contingente policial, mas ainda não tive a ventura de chegar ao Shangri-la (Opinião, p. 2, 23 a 29 abr. 1973).

A declaração de Sérgio Augusto sintetiza o debate dos leitores à questão do utilitarismo da arte e sua dependência da política, mostrando a necessidade de explicar ao público a função estética do cinema e sua autonomia das demais produções culturais. 
A polêmica acima descrita entre os leitores foi motivada pela ideia de veracidade, naturalismo e impressão de realidade no cinema. É interessante notar quanto as idéias do próprio jornal repercutem de forma absolutamente distorcida nesta coluna dos leitores. É possível, inclusive, perceber como o processo de desvendamento do discurso dos filmes feito pelos críticos era difícil de ser entendido pelo público. Desvendando a veracidade histórica e o naturalismo, os críticos de Opinião e Movimento defendiam filmes históricos que partissem do cinema moderno porque estes revelariam a fabricação da realidade aos leitores. Contudo, as opiniões dos leitores ainda defendiam o cinema clássico numa busca pela representação "verdadeira" do processo histórico. Em síntese, eles ainda exigiam a veracidade histórica tanto dos filmes estrangeiros, quanto dos brasileiros.

Finalizamos com a crítica de José Carlos Avellar sobre o lançamento de filmes políticos no Jornal do Brasil ${ }^{9}$. Ele considera Sacco e Vanzetti uma "reconstituição em estilo dramático tradicional do erro judicial e das pressões políticas que levaram a morte" dos dois anarquistas. O crítico não está preocupado em condenar a produção pela caracterização de melodrama ou elogiar algum outro que opte pelas regras do cinema moderno. Prefere tomar por ponto de partida as citações do livro Cinema e Política de Furhammar (1976) para mostrar que o cinema não existe num estado de sublime inocência, porque o conteúdo político inconsciente está sempre presente. Assim qualquer filme sempre foi e sempre será político.

Avellar explica ao espectador a diferença entre os filmes de Godard e de Costa Gravas, sem emitir um juízo de valor de forma explícita. Primeiro, esclarece que Godard faz filmes que fogem do esquema de ilusão da realidade porque quer revelar a repressão social via linguagem cinematográfica tradicional, que costuma dificultar uma tomada crítica de posição do público. E insere o leitor na concepção de Costa Gravas de cinema político que é:

[...] feito ao menos para influenciar os espectadores através da informação. É necessário usar o espetáculo de forma tradicional, construção dramática e utilização de atores para que as pessoas se sintam ligadas e sintam que o filme serve para alguma coisa. O público tem em geral interesse em sofrer com alguém na tela do que assistir às imagens comen- 
Crítica de cinema e política: o filme histórico nos jornais alternativos...

tadas e ser obrigado a refletir sobre uma situação real (Jornal do Brasil, p. 36, 24 mar. 1973).

Sem condenar os filmes de Costa Gravas pela utilização do melodrama, da construção dramática e do sentimento de justiça poética presente na filmografia dele, Avellar procura adotar um tom neutro. Contudo, ele não se furta a fazer um breve comentário sobre a diferença entre os dois tipos de cinema, clássico e moderno, mas sem combater as bases destes dois. Ou seja, não censura o hermetismo de Godard, como se costumava fazer, nem considera Costa Gravas um subproduto de Hollywood. Afirma que "boa parte dos filmes políticos ainda esbarra numa fórmula de espetáculo inadequado para a perfeita compreensão de seus temas". Grande parte "se perde na procura desordenada por uma nova fórmula para ter um ponto de vista crítico". Mas ele considera o saldo dos dois tipos positivo, porque até mesmo "os filmes parcialmente realizados" contribuem para "destruir a falsa ideia" de que política não é para as pessoas comuns.

Como vimos nos exemplos anteriormente citados, a crítica da imprensa alternativa sobre os filmes históricos busca demonstrar ao leitor que, nos filmes, a história do Brasil é trazida como discurso da verdade, como "fabricação do real", para que o espectador se convença que vê no filme um pedaço da realidade que lhe chegou às mãos magicamente pelo cinema. Os críticos enfocam continuamente que os filmes históricos costumam ocultar sua visão de mundo, mas são sempre uma representação da verdade. O intuito é mostrar ao leitor a utilização política dos filmes históricos, postura não adotada pela grande imprensa.

O tipo de crítica de cinema praticado na imprensa alternativa é uma crítica militante que coloca em primeiro plano a relação entre cinema e política. Esta postura tinha relação com o regime militar, mas foi também muito influenciada pelos movimentos cinematográficos dos anos sessenta. O Cinema Novo gerou profundas alterações na postura dos críticos. Eles assumiram uma postura mais participativa no processo de produção cinematográfica, como apontou Jean Claude Bernardet (1979). A mudança na crítica incluiu uma reelaboração de sentido na construção de significados sobre a realidade brasileira. 
Analisando a própria produção, Jean Claude Bernardet (1978) esclarece que na época de Suplemento Literário sua crítica era voltada à análise estética e impressionista dos filmes. Depois de sua passagem pela Última Hora, ele envereda por um outro tipo de crítica, denominada crítica conteudística. Este tipo de crítica está presente nos artigos da imprensa alternativa sobre os filmes históricos. Tratavase de uma crítica centrada no enredo dos filmes, destinada aos espectadores presos a esse tipo de fruição, deixando muitas vezes em segundo plano os aspectos estéticos e da forma da obra. Um dos focos deste tipo de crítica é gerar um processo de conscientização dos leitores sobre a ideologia dos filmes. Essa preocupação da crítica de conteúdo em desmascarar a ideologia da produção encontra confluência com os objetivos da imprensa alternativa, que tinha inspiração gramsciana e entendia os jornais como entidades autônomas com o propósito de contribuir para a formação de uma consciência crítica nacional (KUCINSKI, 1991). Mostrando o caráter ideológico destes filmes, estes jornais buscaram mais do que informar, gerar consciência crítica do leitor.

Gerar consciência crítica, no caso do cinema, era relacionar a produção de filmes brasileiros com a política cultural e o projeto ideológico do Estado. Nesta postura, os jornais alternativos Opinião e Movimento tornaram indissociável cinema e política. Durante os anos setenta, o filme histórico chamou a atenção da crítica por causa de sua relação com a produção do Estado. Esta discussão ocupou um espaço considerável na crítica de Opinião e Movimento para revelar aos leitores a tentativa do governo de dar algum tipo de orientação temática à produção de filmes.

No geral, a imprensa alternativa desempenhou um papel diferenciado ao tentar desmascarar os pressupostos de qualidade dos filmes históricos (impressão de realidade e naturalismo na interpretação dos atores). Os críticos procuraram mostrar que não trata-se de procurar a verdade no cinema, mas que existe apenas representação e discurso, uma polêmica que acompanhou a discussão da crítica de cinema nos anos setenta em nível mundial. Acima de tudo, a imprensa alternativa procurou conscientizar os leitores de que o importante, do ponto de vista político, são os filmes que geram reflexões. 


\section{CINEMA CRITICISM AND POLITICS: THE HISTORICAL FILM IN THE UNDERGROUND NEWSPAPERS OPINIÃO AND MOVIMENTO}

Abstract: During the seventies, the increase of the historical films production was a form which the State has found to guide the production through the Embrafilme sponsorship. The present paper analyses the critics thinking of Opinião and Movimento to assess the underground press contributions about the historical films: Carlos Coimbra's Independência ou Morte (1972), Joaquim Pedro de Andrade's Os inconfidentes (1972) and Giuliano Montaldo's Sacco e Vanzetti (1971).

Keywords: Cinema criticism. Historical film. Underground newspaper. Os Inconfidentes. Sacco e Vanzetti.

\section{Notas}

${ }^{1}$ O filme histórico brasileiro. Filme Cultura. v. 7, n. 23, p. 32-5, jan./fev. 1973.

${ }^{2}$ Com as armas do inimigo. Opinião. n. 126, p. 20, 11 abr. 1975.

${ }^{3}$ O cinema investiga a bistória (um compromisso com o presente). Movimento. v. 1, n. 5, p. 21, 04 ago. 1975.

${ }^{4}$ Veredas da tela. Movimento. v. 2, n. 29, p. 20, 19 jan. 1976.

${ }^{5}$ Sobre análise de filmes a partir do processo de monumentalização fílmica, ver a tese de Morettin (2001) e o artigo de Marcos Napolitano "A escrita fílmica da história e a monumentalização do passado - uma análise comparativa de Amistad e Danton". (Capelato, 2007).

${ }^{6}$ Um melodrama de tribunal. Opinião. n. 20, p. 21, 19 a 26 mar. 1973.

7 Sacco e Vanzetti, um debate. Opinião. n. 23, p. 2, 9 a 16 abr. 1973.

${ }^{8}$ Polêmica provinciana e estéril. Opinião. n. 25, p. 2, 23 a 29 abr. 1973.

${ }^{9}$ Cinema Político. Jornal do Brasil. p. 36, 24 mar. 1973.

\section{Referências}

AMENGUAL, Barthélemy et al. Cinema, arte e ideologia. Porto: Afrontamento, 1975. BAECQUE, Antoine. Cinefilia - invenção de um olhar, historia de uma cultura 1944-1968. São Paulo: Cosac Naify, 2010. [2003]

BERNARDET, Jean Claude (Org.) Anos setenta: cinema. Rio de Janeiro, Ed. Europa, 1979-1980. . Brasil em tempo de cinema. Rio de Janeiro, Civilização Brasileira, 1967. 


\section{Margarida Maria Adamatti}

BERNARDET, Jean Claude. Cinema Brasileiro: propostas para uma história. Rio de Janeiro: Paz e Terra, 1979.

. Piranha no Mar de Rosas. São Paulo: Nobel, 1982.

Trajetória Crítica. São Paulo: Polis, 1978.

BYWATER, Tim; SOBCHACK, Thomas. Introduction to film criticism. New York/ London: Longman, 1989.

CAMARGO, Maria Fernanda Ferrez de. A crítica de e a crítica sobre o cinema em Opinião. 2009. Trabalho de Conclusão de Curso (Curso Superior de Audiovisual) - Escola de Comunicações e Artes, Universidade de São Paulo, São Paulo.

CAPELATO, Maria Helena. História e Cinema. São Paulo: Alameda, 2007.

CHINEM, Rivaldo. Imprensa alternativa - jornalismo de oposição e inovação. São Paulo: Ática, 1995.

FESTA, Regina; DA SILVA, Carlos Eduardo Lins. Comunicação popular e alternativa no Brasil. São Paulo, Edições Paulinas, 1986.

FURHAMMAR, Leif; FOLKE, Isaksson. Cinema e politica. Rio de Janeiro: Paz e Terra, 1976.

GOMES, Paulo Emilio Salles. Cinema: Trajetória no subdesenvolvimento. Rio de Janeiro: Embrafilme/Paz e Terra, 1980. Publicado na revista Argumento. São Paulo, n. 1 , out. 1973.

HILLIERS, Jim; BROWNE, Nick. Cahiers du Cinéma: 1960-1968: New Wave, New Cinema, Re-evaluating Hollywood. London: Routledge, 1996. v. 2.

KENSKI, Vani Moreira. O fascínio de Opinião. Doutorado em Educação. 1990. Campinas, Faculdade de Educação da Universidade Estadual de Unicamp.

KUCINSKI, Bernardo. Jornalistas e revolucionários - nos tempos da imprensa alternativa. São Paulo: Editora Página Aberta, 1991.

LE GOFF, Jacques. “Documento/Monumento”. In: História e Memória. Campinas, Editora da Unicamp, 1998.

MARCONI, Paolo. A censura política na imprensa brasileira (1968-1978). São Paulo: Global Editora, 1980.

MARQUARDT, Eduard. Cultura em Opinião - as páginas de Tendências Culturais (1972-1977). 2003. Dissertação (Mestrado em Literatura). Centro de Comunicação e Expressão, Universidade Federal de Santa Catarina, Florianópolis.

MORETTIN, Eduardo Victorio. Os limites de um projeto de monumentalização cinematográfica. Uma análise do filme "Descobrimento do Brasil" (1937). 2001. Tese (Doutorado em Artes). Escola de Comunicações e Artes, Universidade de São Paulo, São Paulo, 2001. 
Crítica de cinema e política: o filme histórico nos jornais alternativos...

MOURÃO, Dora; CAETANO, Maria de Rosário; BACQUÉ, Laure. Jean-Claude Bernardet: uma homenagem. São Paulo: Imprensa Oficial do Estado de São Paulo/ Cinemateca Brasileira, 2007.

PRUDENZI, Ângela; RESEGOTTI, Elisa. Cinema politico italiano - anos 60 e 70. São Paulo: Cosac Naify, 2006.

D RAMOS, Alcide (Org.). O canibalismo dos fracos, cinema e história do Brasil. Bauru: Edusc, 2002.

SIMÕES, Inimá. O imaginário da Boca. São Paulo, Secretaria Municipal de Cultura, 1981.

Roteiro da intolerância - a censura cinematográfica no Brasil. São Paulo: Editora Senac, 1999.

XAVIER, Ismail. O discurso cinematográfico - a opacidade e a transparência. São Paulo: Paz e Terra, 2005.

WILSON, David. Cahiers du Cinéma: 1973-1978: History, Ideology, Cultural Struggle. London: Routledge, 2000.

Recebido em 14/07/2012

Aprovado em: 11/12/2012 